\title{
Pengaruh Reward Dan Punishment Terhadap Kinerja Karyawan KFC Artha Gading
}

\author{
Rizki Ayu Pramesti \\ Sofia. A. P. Sambul \\ Wehelmina Rumawas \\ Jurusan Ilmu Administrasi, Program Studi Administrasi Bisnis \\ Fakultas Ilmu Sosial dan Politik, Universitas Sam Ratulangi Manado \\ ririinez96@gmail.com
}

\begin{abstract}
This study aims to determine the effect of Reward and Punishment on the Employee Performance of KFC Artha Gading North Jakarta. Reward is a form of appreciation to a certain achievement given, both by and from individuals or an institution which is usually given in the form of material or speech. Punishment is a way to direct a behaviour in accordance with the behaviour that applies in general. Performance is the result or level of success of a person as a whole during a certain period in carrying out tasks compared to various possibilities, such as standard results of work, targets or targets or criteria that have been determined in advance and have been agreed upon. This study uses a quantitative approach, with a sample of 32 respondents who are employees of KFC Artha Gading North Jakarta. Research results show that : reward has a positive and significant effect on the performance of employees of Artha Gading Jakarta, punishment has a positive and significant effect on the performance of employees of Artha Gading Jakarta, reward and positive and significant effect on the performance of employees of Artha Gading Jakarta. Punishment has a positive and significant effect on the performance of employees of Artha Gading Jakarta.
\end{abstract}

Keywords: Reward, Punishment and Employee Performance

\section{Pendahuluan}

Dalam perkembangan dunia bisnis yang semakin meningkat, mendorong semakin tinggi pula tingkat persaingan dalam bidang usaha, tidak terkecuali dalam sektor jasa. Seringkali dengan perkembangan tersebut, masalah yang dialami perusahaan semakin komplek karena perusahaan akan menghadapi lebih banyak pesaing namun perusahaan dituntut untuk dapat mencapai penjualan produk sesuai dengan target yang diharapkan melalui peningkatan kualitas pelayanan sumber daya manusia. Kualitas pelayanan sumber daya manusia yang maksimal terhadap konsumen sangat diperlukan dalam menjaga dan meningkatkan kualitas perusahaan. Untuk memacu semangat kerja karyawan, perusahaan harus memenuhi beberapa kriteria melalui penerapan teknik manajemen SDM dan penerapan konsep dimana hal tersebut mencakup peran, pengelolaan serta pendayagunaan karyawan dengan cara memberikan reward dan 
punishment. Reward dan punishment sangat pen-ting dalam memotivasi kinerja karyawan. Karena melalui reward dan punishment karyawan akan menjadi lebih berkualitas dan bertanggung-jawab dengan tugas yang diberikan.

Reward dan Punishment diterapkan pada salah satu bisnis waralaba yaitu KFC. Bisnis waralaba ini semakin berkembang dengan pesat. KFC atau dulu dikenal dengan nama Kentucky Fried Chicken, didirikan oleh Col. Harland Sanders, KFC dikenal terutama karena ayam gorengnya yang krispi. Oleh karna itu penulis ingin mengetahui lebih jauh mengenai reward dan punishment di perusahaan tersebut.

Berdasarkan observasi awal oleh penulis pada KFC Artha Gading Jakarta didapatkan bahwa ada beberapa karyawan yang datang terlambat, adanya kesalahan perbandingan pembuatan adonan, kesalahan delivery yang mengakibatkan kerugian perusahaan tersebut yang bisa mempengaruhi reward dan punishment terhadap kinerja karyawan dan juga bisa mengakibatkan perusahaan tersebut kehilangan konsumen. Dengan permasalahan di atas, penulis akan membahas dan mengkaji lebih lanjut masalah tersebut dengan judul "Pengaruh reward dan punishment terhadap kinerja karyawan KFC Artha Gading Jakarta".

\section{Sumber Daya Manusia}

Sumber daya manusia dalam konteks bisnis adalah orang yang bekerja dalam suatu organisasi atau yang sering juga disebut karyawan. Sumber daya manusia merupakan aset yang paling penting yang harus dimiliki oleh organisasi dan harus diperhatikan dalam manajemen, karena mereka inilah yang bekerja membuat tujuan, mengadakan inovasi dan mencapai tujuan organisasi. Sumber daya manusia inilah yang dapat membuat sumber daya lain dapat berjalan, Rumawas (2018).

\section{Manajemen Sumber Daya Manusia}

Manajemen sumber daya manusia adalah bagian dari ilmu manajemen yang lebih khusus penerapannya terhadap sumber daya manusia. Pengelolaan sumber daya manusia tidak semudah manajemen sumber daya lain, karena yang diatur adalah manusia yang memiliki akal, perasaan dan tujuan yang berbeda, maka keberhasilan atau kegagalan manajemen sumber daya manusia akan berdampak sangat luas.

\section{Reward dan Punishment}

Reward adalah salah satu metode untuk memotivasi seseorang untuk melakukan kebaikan dan meningkatkan prestasinya. Reward adalah ganjaran, hadiah, penghargaan atau imbalan yang 
bertujuan agar seseorang menjadi lebih giat lagi usahanya untuk memperbaiki atau meningkatkan kinerja yang telah dicapai. Reward dapat diartikan sebuah bentuk apresiasi kepada suatu prestasi tertentu yang diberikan, baik oleh dan dari perorangan ataupun suatu lembaga yang biasanya dalam bentuk material atau ucapan (Fitri, Ludigdo \& Djamhuri, 2013). Reward yang diberikan kepada karyawan akan memberikan pengaruh yang signifikan terhadap kinerja.

Sedangkan Punishment adalah sebuah cara untuk mengarahkan sebuah tingkah laku agar sesuai dengan tingkah laku yang berlaku secara umum. Punishment adalah suatu konsekuensi yang tidak menyenangkan atau tidak diinginkan yang diberikan oleh atasan atas suatu perilaku tertentu yang telah dilakukan. Punishment (hukuman) jika digunakan secara efektif dapat menekan perilaku dalam organisasi, dengan kata lain punishment sebaiknya diberikan setelah melalui pertimbangan yang cermat dan objektif dari semua aspek yang relevan dengan situasi yang terjadi.

Dalam hal ini, hukuman akan diberikan ketika sebuah tingkah laku yang tidak diharapkan ditampilkan oleh orang yang bersangkutan atau orang yang bersangkutan tidak memberikan respon atau tidak menampilkan sebuah tingkah laku yang diharapkan.
Reward dan punishment merupakan suatu konsep yang dikembangkan dari suatu konsep manajemen sumber daya manusia, terutama ditujukan dalam rangka memotivasi seseorang untuk melakukan kebaikan dan meningkatkan prestasinya. Kedua metode ini sudah cukup lama dikenal dalam dunia kerja. Tidak hanya dalam dunia kerja, dalam dunia pendidikan pun kedua ini kerap kali digunakan (Mangkunegara, 2015). Reward dan punishment juga sering disebut dengan manajemen bonus dalam suatu suatu organisasi, dan menjadi prioritas dalam mengambil penilaian terhadap kinerja karyawan yang dilakukan oleh pimpinan.

\section{Kinerja Karyawan}

Istilah kinerja berasal dari kata $J o b$ Performance atau Actual Performance (prestasi kerja atau prestasi sesungguhnya yang dicapai oleh seseorang). Kinerja (prestasi kerja) adalah hasil kerja secara kualitas dan kuantitas yang dicapai oleh seorang pegawai dalam melaksanakan tugasnya sesuai dengan tanggung jawab yang diberikan kepadanya. (Mangkunegara 2015). sedangakan Kinerja karyawan adalah hasil dari proses pekerjaan tertentu secara berencana pada waktu dan tempat dari karyawan serta organisasi bersangkutan. Kinerja adalah seperangkat hasil yang dicapai dan merujuk pada tindakan 
pencapaian serta pelaksanaan sesuatu pekerjaan yang diminta. Kinerja dapat juga diartikan sebagai prestasi kerja atau hasil kerja. Kinerja adalah suatu hasil kerja yang di capai seseorang dalam melaksanakan tugas-tugas yang diberikan kepadanya (Hasibuan, 2013).

\section{Metode Penelitian}

Dalam penelitian yang dilakukan pada Kentucky Fried Chicken Artha Gading Jakarta, penulis menggunakan metode penelitian kuantitatif. Populasi dan sampel dalam peneliian ini yaitu seluruh karyawan KFC Artha Gading Jakarta yang berjumlah 32 responden. Teknik pengumpulan data yaitu kuesioner dan observasi dengan dinilai menggunakan skala likert, dan model analisis yang digunakan yaitu analisis regresi berganda.

\section{Hasil Penelitian}

Hasil pengujian validitas data diperoleh 6 item pernyataan variabel reward dinyatakan valid karena mempunyai nilai pearson correlation lebih dari 0,349 . Sedangkan hasil uji reliabilitas menunjukan bahwa nilai Cronbach alpha dari tiap-tiap variabel lebih besar dari 0,7 yang berarti bahwa kuesioner yang digunakan yang diambil dari indikator-indikator variabel tersebut reliable atau handal. Dimana variabel reward (X1) nilai Cronbach alpha sebesar 0,794, punishment (X2) 0,778 dan kinerja karyawan (Y) sebesar 0,774.

Persamaan regresi linier berganda digunakan untuk mengetahui seberapa besar nilai kinerja karyawan bila nilai reward berubah. Berdasarkan persamaan regresi linier berganda diperoleh $\mathrm{Y}=19.062$ $+0,202$ X1. Hal ini berarti bila reward ditingkatkan maka kinerja karyawan juga mengalami peningkatan. Berdasarkan perhitungan koefisien determinan diketahui pengaruh variabel independent reward dan punishment terhadap variabel dependent kinerja karyawan sebesar 0,482 atau 48,2\% sedangkan sisanya $51,8 \%$ dipengaruhi variabel lain yang tidak dalam penelitian ini.

Dari hasil analisis menunjukan hasil uji $\mathrm{t}$ diperoleh $\mathrm{t}$ hitung untuk variabel reward adalah sebesar 0,652 dengan signifikansi 0,000 . Nilai sig uji t yang lebih kecil $(<)$ dari 0,05 yang menunjukan diterima hipotesis yang menyatakan Reward (penghargaan) berpengaruh positif terhadap kinerja karyawan pada KFC Artha Gading.

Hasil pengujian validitas data diperoleh 5 item pernyataan variabel punishment dinyatakan valid karena mempunyai nilai Pearson correlation lebih dari 0,349. Sedangkan hasil uji reliabilitas menunjukan bahwa nilai Cronbach alpha dari tiap-tiap variabel lebih besar dari 0,7 
yang berarti variabel tersebut reliable atau handal. Dimana variabel reward (X1) nilai Cronbach alpha sebesar 0,794, punishment (X2) 0,778 dan kinerja karyawan (Y) sebesar 0,774 .

Persamaan regresi linier berganda digunakan untuk mengetahui seberapa tinggi nilai kinerja karyawan apabila nilai punishment berubah. Berdasarkan hasil uji pada spss versi 25 diperoleh persamaan regresi linier berganda sebagai berikut : $\mathrm{Y}=$ $19.062+1.782 \mathrm{X} 2$. hal ini berarti jika nilai punishment ditingkatkan maka kinerja karyawan juga mengalami peningkatan. Berdasarkan perhitungan koefisien determinan yang diperoleh maka dapat diketahui bahwa persentase pengaruh variabel independen punishment terhadap variabel dependen kinerja karyawan sebesar 0,482 atau 48,2\% sedangkan sisanya $51,8 \%$ dipengaruhi variabel lain yang tidak dalam penelitian ini. Persamaan regresi linier berganda untuk melakukan seberapa tinggi nilai kinerja karyawan bila nilai reward dan punishment berubah.

Dari hasil analisis menunjukan hasil uji $\mathrm{t}$ diperoleh $\mathrm{t}$ hitung untuk variabel punishment adalah sebesar 3.996 dengan signifikansi 0,000. Nilai sig uji t yang lebih kecil (<) dari 0,05 yang menunjukan diterima hipotesis yang menyatakan punishment berpengaruh positif terhadap kinerja karyawan pada KFC Artha Gading.
Berdasarkan hasil analisis diperoleh persamaan $\mathrm{Y}=19.062+0,202 \mathrm{X} 1+1.782$ X2 hal ini berarti bila reward dan punishment ditingkatkan maka kinerja karyawan juga mengalami peningkatan.

Berdasarkan hasil uji $\mathrm{F}$ diperoleh bahwa adanya pengaruh secara bersamaan dari dua variabel independent (reward dan punishment) terhadap kinerja karyawan menunjukan hasil yang positif. Hal tersebut ditunjukan dari besarnya nilai $\mathrm{F}$ hitung sebesar 13.478 dan dengan tingkat signifikan 0,000 dimana lebih kecil dari 0,05. Dengan adanya kedua metode tersebut maka kinerja karyawan akan semakin meningkat dan karyawan mampu melaksanakan pekerjaannya dengan baik. Sehingga dapat dikatakan bahwa reward dan punishment merupakan kedua hal yang dapat memotivasi karyawan untuk meningkatkan kinerjanya.

\section{Pembahasan}

Reward berpengaruh positif terhadap kinerja karyawan apabila sistem reward semakin adil yaitu adannya gaji dan bonus, kesejahteraan, pengembangan karir maka kinerja karyawan akan semakin meningkat yaitu dengan mampu melaksanakan pekerjaannya dengan baik secara berkualitas, memiliki ketepatan waktu, efektivitas dan memiliki kemandirian. Reward sangat penting bagi setiap indiividu 
karyawan yang mau bekerja keras dan antusias untuk meningkatkan kinerja karyawan. Pimpinan harus menyadari, bahwa karyawan akan mau bekerja keras dengan harapan, dapat memenuhi kebutuhan dan keinginan dari hasil pekerjaannya. Dengan adanya punishment karyawan akan lebih disiplin dan teliti serta mampu melaksanakan tugas pekerjaannya sehingga mampu meningkatkan kinerja. Dengan demikian jika variabel ini dihubungan secara bersama-sama terhadap kinerja karyawan maka akan diperoleh dampak yang lebih tinggi. Dimana jika reward tinggi dan punishment baik maka akan meningkatkan kinerja lebih baik lagi.

Penelitian ini didukung oleh penelitian sebelumnya yang dilakukan oleh Maksipreneur (2015) Yang menunjukan bahwa reward dan punishment memiliki pengaruh positif secara bersama-sama dan signifikan terhadap kinerja karyawan KFC Artha Gading.

\section{Kesimpulan}

Hasil penelitian menunjukkan bahwa variabel reward (X1) berpengaruh positif dan signifikan terhadap kinerja karyawan KFC Artha Gading. Hal ini dikarenakan bahwa dengan adanya Reward membuat karyawan lebih gembira dan produktif lagi dalam melakukan pekerjaannya. Hasil penelitian menunjukkan bahwa variabel punishment (X2) berpengaruh positif dan signifikan terhadap kinerja karyawan KFC Artha Gading. Hal ini dikarenakan bahwa adanya Punishment membatasi perilaku, agar tidak terjadi tingkah laku yang tidak diharapkan.

Hasil pengujian dengan menggunakan uji $\mathrm{F}$ yang disajikan pada tabel di atas menunjukkan bahwa variabel reward dan punishment memiliki nilai Fhitung = 13.478 dengan sig $=0,000$ hal ini menunjukkan bahwa reward dan punishment secara simultan berpengaruh positif dan signifikan terhadap kinerja karyawan KFC Artha Gading.

\section{Saran}

Berdasarkan hasil yang diperoleh maka peneliti ingin memberikan saransaran sebagai berikut :

Berdasarkan hasil penelitian yang menyatakan bahwa adanya pengaruh reward terhadap kinerja karyawan maka alangkah lebih baik untuk dapat mempertahankan dan lebih memperhatikan lagi terhadap pemberian reward kepada karyawan sehingga bisa berdampak terhadap kinerja para karyawan karena jika pemberian reward dilakukan dengan baik dan tepat dapat memberikan motivasi dan dorongan kepada seluruh karyawan untuk lebih meningkatkan kinerjanya. Untuk KFC Artha Gading Jakarta jika melakukan 
penetapan Punishment untuk berhati-hati dalam menerapkan punishment yang berlebihan, karena hal ini justru dapat menjatuhkan mental karyawan atau bisa juga demotivasi.

KFC Artha Gading sekiranya mampu mempertahankan dan meningkatkan Reward dan Punishment terhadap Kinerja Karywan, agar kedepannya Perusahaan lebih baik lagi.

\section{Daftar Pustaka}

Fitri S. Massuki, Ludigdo Unti, Djamhuri Ali. 2013. Pengaruh Gaya Kepemimpinan, Komitmen, Organisasi, Kualitas Sumber Daya, Reward dan Punishment Terhadap Anggaran Berbasis Kinerja. Jurnal Dinamika Akuntansi 5

Hasibuan, Malayu S.P. 2013. Manajemen Sumber Daya Manusia. Cetakan Ketujuh Belas. Jakarta : BumiAksara.

Mangkunegara Anwar Prabu, 2015. Manajemen Sumber Daya Manusia Perusahaan. Bandung : Remaja Rosdakarya.

Nugroho Adi Dwi. 2015. Pengaruh Reward dan Punishment Terhadap Karyawan PT Business Training And Empoworing Management Surabaya. Jurnal Maksipreneur 4 (4-14)

Rumawas Wehelmina, 2018. Manajemen Sumber Daya Manusia. Manado : Universitas Sam Ratulangi (Unsrat Press) 